\author{
シンポジウム $\mathrm{I}-3$ \\ サイトカイン（主として IL-1）の Pathophysiology \\ 池 島 喬 - Charles A. Dinarello \\ Jpn. J. Clin. Immun., $9(5): 333 \sim 336,1986$.

\section{Pathophysiology of Cytokines} \\ Takashi Ikejima and Charles A. Dinarello \\ Department of Medicine, Division of Geoglaphic medicine \\ and Infectious Diseases, New England Medical Center Hospitals
}

\title{
[Summary]
}

Toxic shock syndrome toxin-1 (TSST-1) induces IL-1 production from macrophages/ monocytes of various species. Susceptibility of the mouse strains to TSST- 1 is parallel to the IL-1 production. IL-1 has multibiological activities for T cells, hepatocytes, neutrophils, fibroblasts and other cells, resulting in induction of acute phase responses. PI 5 IL-1 (IL1 alpha) and PI 7 (IL-1 beta) are cloned in both the human and the mouse cases (1 3). The recombinant IL-1's confirm the multiple biological properties of the purified IL-1 including fever. IFN-alpha is also an endogenous pyrogen. Recombinant tumor necrosis factor (TNF) possesses almost the same biological function of IL-1. However, TNF induces IL-1 production from human mononuclear cells while IL-1 production by IL-1 itself has never been reported, yet. Differently from IL-1, TNF does not augment $T$ cell proliferation. Although TSST-1 induces only IL-1, endotoxin stimulates both IL-1 and TNF production. A quantitative relationship among these endogenous pyrogens remains unsolved in each disease.

1) Auron, et al. : Proc. Natl. Acad. Sci. USA, $81: 7907,1984$.

2) Lomedico, et al. : Nature, $312: 458,1984$.

3) Gubler, et al. : J. Immunol, $136: 2492,1986$.

\section{I. はじめに}

発熱がヒトや動物に内在する物質によって制御されて いるという考え方は古くからあり，活性化された Leuko. cyte から内因性発熱物啠 (endogenous pyrogen).が放 出されていることが 1940 年代に Menkin や Beeson に

New Eagland Medicol Center Hospitals
よって示された.この内因性発熱物質は Yale 大学の Elisha Atkins らのグループによってその生体における 働きが精力的に研究されてきたが内因性発熱物質がイン ターロイキン (IL-1) と同一物質であることが Rosenwasser ${ }^{1,2)}$ やMurphy ら゙によって確かめられた. 最初 に强力な IL-1 の産生誘導物質である toxic shock syndrome toxin-1 (TSST-1) を例にとってその IL-1 産生 の様子を紹介する. 


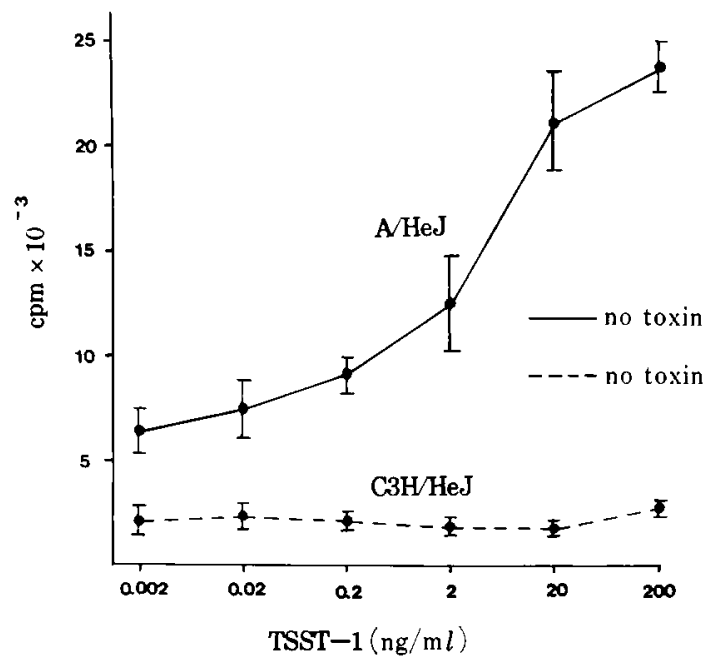

図 1 TSST-1 により誘導された, マウス腹腔 マクロファージからの IL-1 産生 A/HeJ : TSST-1 感受性マウス $\mathrm{C} 3 \mathrm{H} / \mathrm{HeJ}: \mathrm{TSST}-1$ 低感受性マウス

\section{II. toxic shock syndrome $と \mathrm{IL}-1$ 産生}

toxic shock syndrome は James Todd ら4により 1978 年に初めて報告された病気で, 高熱, 下痢, 血圧の 急激な低下，全身性の皮疹，回復期に㧍ける皮虞の剥離 などを伴い，患者の $92 \%$ は月経中の婦人で，そのうち 98\%が発症時にタンポンを使用していた. 主としてSta. phylococcus aureus の腔内にお打る增殖吕認められ, toxic shock 関連菌の培羕上清をウサギに静注すると 4 時問以内に影著な発熱を誘起する. 精製された毒素仕ウ サギ血清中からほぼ 3 時間以内に除去されるが，発熱は 3 時間以降に開始され約 20 時閒にわたって持続する. したがって毒素と発熱の間に別の介在物質の存在が示唆 された. toxic shock 関連菌の培養上清を静注して 4 時間 後の発熱時に採取されたウサギ血清を他のウサギに静注 すると約 15 分後に発熱がみられ，IL-1 などの内因性発 熱物質の関与が予想された，精製された TSST-1 はヒ 卜単核球に IL-1 の産生を誘起する5). TSST-1 と内毒素 に感受性で発熱する A/HeJ マウスと TSST-1 や内毒素 に感受性の低いC3H/HeJ マウスでは TSST-1によって 刺激された腹腔内マクロファージからの IL-1 の分泌に 顕著な差がみられる (図 1).しかるにこれら2 系統のマ ウスのリコンビナントマウス IL-1 に対する発熱反応に は差がみられないことから，毒素に対する感受性は IL1 の生産量と相関していることが示された（表 1). ヒト とマウスでは異なる遗伝子に制御された PI 5 タイプ
表 1 Febrile responses of two strains of mice to TSST-1 and interleukin 1

\begin{tabular}{lrlrl}
\hline Strain & $\begin{array}{r}\text { TSST-1 response } \\
(\mu \mathrm{g} / \mathrm{kg})\end{array}$ & $\begin{array}{r}\text { mr IL-1 response } \\
(\mu \mathrm{g} / \mathrm{kg})^{\mathrm{a}}\end{array}$ \\
\hline $\mathrm{A} / \mathrm{HeJ}$ & 0.3 & $+^{\mathrm{b}}$ & 0.4 & + \\
& 1.5 & $\mathrm{H}$ & 0.8 & $\mathrm{H}$ \\
\hline $\mathrm{C} 3 \mathrm{H} / \mathrm{HeJ}$ & 0.3 & - & 0.4 & + \\
& 1.5 & - & 0.8 & $\mathrm{H}$ \\
\hline
\end{tabular}

a Mouse recombinant $\mathrm{IL}-1$

b Febrile responses. $+: 0.5 \sim 1.0^{\circ} \mathrm{C}$ $+: 1.0 \sim 1.5^{\circ} \mathrm{C}$ HI: $1.5^{\circ} \mathrm{C} \sim$

(IL-1 $\alpha)$ と PI 7 タイプ (IL-1 $\beta$ ) の存在が確認されて 拉り，その生物活性の差はみられていない，ヒトとマウ スリコンビナントIL-1 はウサギやマウスに典型的な IL-1 性発熱を約 30 分以内に誘起する6). IL-1 のような 内因性発熱物質は視床下部からアラキドン酸を放出さ せ，その代祔物質の一種であるプロスタグランディン $\mathrm{E}_{2}\left(\mathrm{PGE}_{2}\right)$ が体温調節スイッチを高温側にセットしてい ると考えられるが7，IL-1 処理された滑液細胞や笳肉細 胞においても $\mathrm{PGE}_{2}$ の増加が検出されている. IL-1 の生 物活性は多岐にわたり， $\mathrm{T}$ 細胞， B 細胞， NK 細胞の活性 化のほかに低亜鉛血症，低鉄血症，高銅血症，好中球の 増多, フィブリノーゲンや血清アミロイドーA のような 急性期蛋白の上昇, 笳肉中における蛋白質の崩壊そして 内皮細胞への好中球の付着促進などを誘遒する．メラ， ーマに対する細胞毒性 ${ }^{18)}$ や膵ランゲルハンス島 $\beta$ 細胞 に対する細胞毒性 ${ }^{9}$ も最近報告されている.

\section{III. 内因性発熱物質としての $\boldsymbol{\alpha}$ インター$$
\text { フェロン }(\text { IFN-a) }
$$

ウサギに IFN- $\alpha$ 毎日 $5 \times 10^{6} \mathrm{U} / \mathrm{kg}$ 静注するとトレ ランスを伴わない発熱が誘起され（内因性発熱物質の特 徽)，ウサギ視床下部の破砕断片に IFN- $\alpha$ を加えて培養 すると 30 分以内に $\mathrm{PGE}_{2}$ 産生がみられることから $\mathrm{IFN}-$ $\alpha$ はそれ自体が内因性発熱物質であり，その発熱は IL-1 同様に $\mathrm{PGE}_{2}$ 量の増大を介して行われていることが示唆 されている10). ほかに B 細胞や NK 細胞の活性化, マ クロファージの抗腫瘍活性の上昇の誘起などが IL-1 と 共通している.

\section{IV. 腫瘍壊死因子（TNF）}

リコンビナント TNF をウサギに静注すると約 30 分 後に投与量に対応する発熱がウサギに誘導される11. $\mathrm{PGE}_{2}$ の産生阻害剤である ibuprofen な TNF 静注の 10 
分前に静注すると発熱は阻害される.TNFを多量 10 $\mu \mathrm{g} / \mathrm{kg}$ 静注すると約 3 時間後に第 2 の発熱ピークが誘導

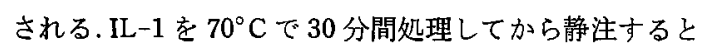
発熱誘導能力を失うが, TNF は発熱誘導能をかなり保持 しており，10 $\mu \mathrm{g} / \mathrm{kg}$ 投与した場合にみられる第 2 の発熱 は熱処理によって失われても第 1 の發熱は残る.ibuprofen による前処理は TNF のウサギにおける発熱誘尊能 をすべて失わせる，第 2 の発熱時のウサギ血清を他のウ サギに静注すると約 30 分後に第 1 の発熱のみが誘導さ

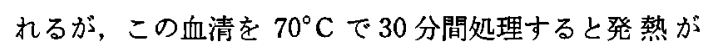
みられなくなることから第 2 の発熱俚血清中に残存する TNF ではなく，IL-1 のような他の内因性発熱物翼によ って誘導されていることが示唆される. $50 \mu \mathrm{g} / \mathrm{m} l$ 量の $\mathrm{TNF}$ をと卜単核球培養に加えて，その培養上清をウサ ギに静注すると発熱が誘導されるが培盖上清はTNFに はみられないマウス胸腺細胞の分裂促進能を有し，その 活性は抗 IL-1 抗体によって抑制される. ゆえに TNF によって誘導された発熱のうち第 1 の発熱は内因性発熱

1) Rosenwasser, L.J., Dinarello, C.A., Rosenthal, A.S. : Adherent cell function in murine T-lymphocyte antigen recognition. IV. Enhancement of murine $T$ cell antigen recognition by human leukocytic pyrogen. J. Exp. Med., 150:709, 1979.

2) Rosenwasser, L.J., Dinarello, C.A. : Ability of human leukocytic pyrogen to enhance phytohemagglutinin induced murine thymocyte proliferation. Cell. Immunol., $63: 134,1981$.

3) Murphy, P.A., Simon, P.L., Willoughby, W.F.: Endogenous pyrogens made by rabbit peritoneal exudate cells are identical with lymphocyte activating factors made by rabbit alveolar macrophages. J. Immunol., $124: 2498,1980$.

4) Todd, J.M., Fishant, M., Kapral, M. : Toxicshock syndrome associated with phase -group-1 staphylococci. Lancet, II : 1116, 1978.

5) Ikejima, T., Dinarello, C.A., Gill, D.M., Wolff, S.M. : Induction of human interleukin-1 by a product of Staphylococcus aureus associated with toxic shock syndrome. L. Clin. Invest., 73 : 1312, 1984.

6) Dinarello, C.A., Cannon, J.G., Mier, J.W.,
因子であるTNF によって誘遒され，第 2 の発熱はTNF によって誘導された IL-1 の産生によるものであること が判る. IL-1 と TNF の多様な生物活性はほぼ共通して いるが TNF は T cell の分裂を促進しない，また TNF は IL-1 の生産を誘遒するのに対し IL-1 が TNF の産 生を誘導する事実は報告されていない，

\section{V. ま とめ}

つい近時まで IL-1 が唯一の内因性発熱物質のように 報告されてきたが，IL-1 のほかに IFN- $\alpha$ 个NF も内 因性発熱物質であり多くの共通の多様な生物活性を有す ることが判ってきた. TSST-1 は IL-1 を誘導するが TNF を誘導しない. 内毒素は IL-1 と TNF の双方の産 生を誘遒するが, TNF は IL-1 の誘導物質でもある。嘒 素と誘導される内因性発熱物質の種類，そして内熱性発 熱物質同士の相互関係を包括的に理解することが多くの 病状の解明に役立つと思われる。

献

Bernheim, H.A., LoPreste, G. Lynn, D.L., Love, R.N., Webb, A.C., Auron, P.E., Reuben, R.C., Rich, A., Wolff, S.M., Putney, A.D. : Multiple biological activities of human recombinant interleukin 1. J. Clin. Invest., $77: 1734$, 1986.

7) Bernheim, H.A., Gilbert, T.M., Stits, J.T. : Prostaglandin $\mathrm{E}$ levels in third ventricular cerebrospinal fluid of rabbits during fever and changes in body temperature., J. Physiol., $301: 69,1980$.

8) Lackman, L.B., Dinarello, C.A., Lanson, N.D., Fidler, I.J. : Natural and recombinant human interleukin $1-\beta$ in cytotoxic for human melanoma cells. J. Immunol., $136: 3098,1986$.

9) Bendzen, K., Mandrup-Poulsen, T., Nerup, J., Nielsen, J.H., Dinarello, C.A., Svenson, M. : Cytotoxicity of human PI 7 interleukin-1 for pancreatic islets of Langerhans. Science, 232 : $1545,1986$.

10) Dinarello, C.A., Bernheim, H.A., Duff, G.W., Le, H.V., Nagabhushan, T.C., Hamilton, N.C., Coceani, F. : Mechanisms of fever induced by recombinant human interferon. J. Clin. Invest., 
$74: 906,1984$.

11) Dinarello, C.A., Cannon, J.G., Wolff, S.M., Bernheim, H.A., Beutler, B., Cerami, A., Figari, I.S., Palladino, M.A.Jr., O'Connor, J.V. :
Tumor necrosis factor (cachectin) is an endo. genous pyrogen and induces production of interleukin 1. J. Exp. Med., 163 : 1433, 1986. 